\title{
miR-22 I Suppression Through Nanoparticle-Based miRNA Delivery System for Hepatocellular Carcinoma Therapy and Its Diagnosis as a Potential Biomarker [Corrigendum]
}

\author{
Li F, Wang F, Zhu C, Wei Q, Zhang T, Zhou YL. \\ Int J Nanomedicine. 2018;13:2295-2307.
}

The authors have advised Figure 2B on page 2301 is incorrect. Due to an error at the time of figure assembly
B1 and B2 were duplicated. The correct Figure 2 is shown below.

The authors apologize for this error and advise it does not affect the results of the paper. 
A
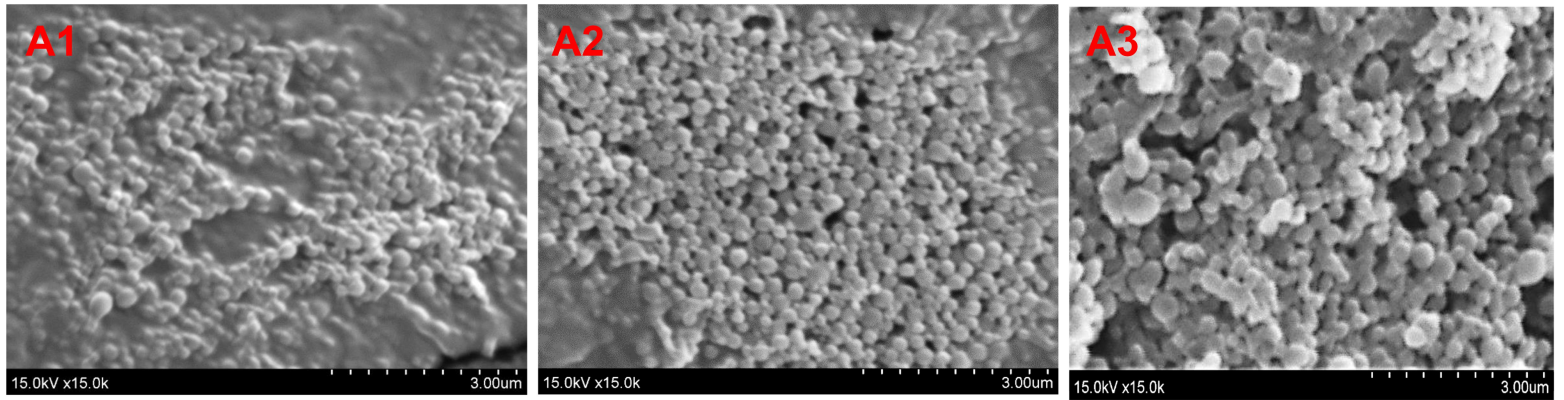

B
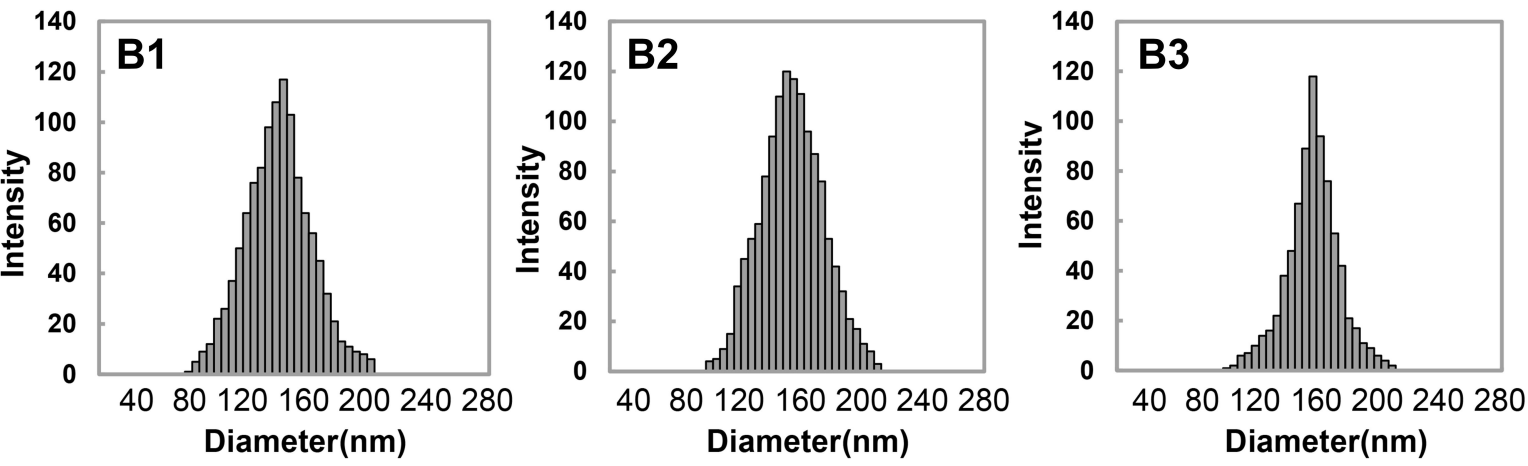

C

D
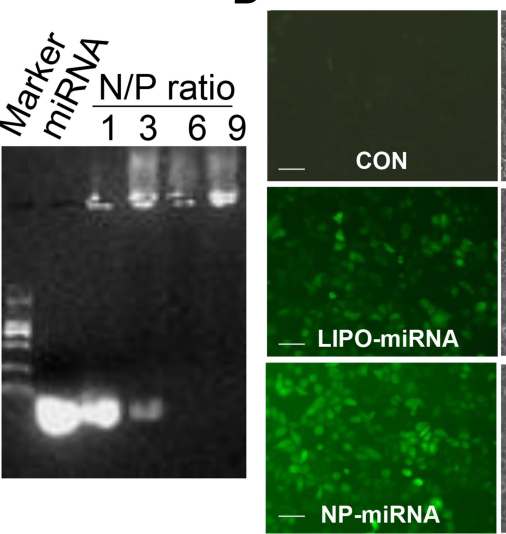

HepG2
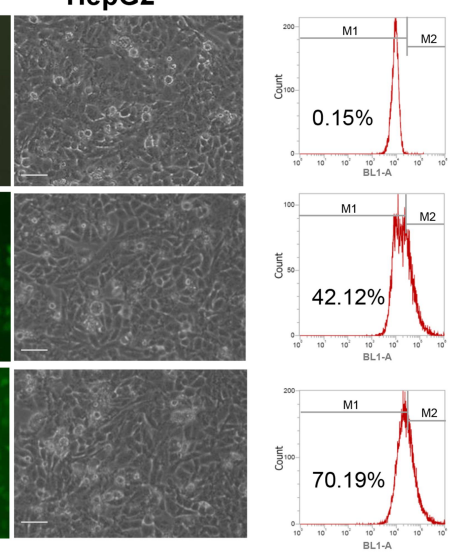

E
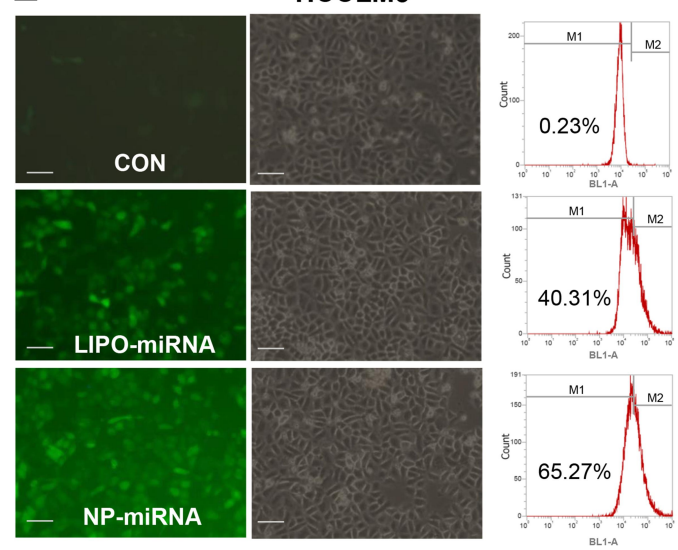

Figure 2 Characterization and transfection efficiency of nanoparticle/miRNA complexes.

Notes: (A) Typical SEM images of the PLGA nanopartitcles (AI), PEl-modified nanoparticles (A2), and nanoparticle/miRNA complexes (A3); magnification I5,000×. (B) Hydrodynamic diameter distribution of the PLGA nanoparticles (BI), PEl-modified nanoparticles (B2), and nanoparticle/miRNA complexes (B3). (C) Agarose gel electrophoresis assay of miRNA/nanoparticle complexes at different N/P ratios. (D and $\mathbf{E}$ ) Typical fluorescent images, corresponding bright images, and transfection efficiency of cells transfected with nanoparticle/FAM-miRNA complexes or lipofectamine/FAM-miRNA complexes. The scale bar represents I00 $\mu$ m; magnification is $200 \times$. Abbreviations: CON, control; LIPO, lipofectamine; miRNA, microRNA; NP, nanoparticle; PLGA, poly(lactic-co-glycolic) acid; SEM, scanning electron microscopy; PEI, polyethylenimine.

International Journal of Nanomedicine

Dovepress

\section{Publish your work in this journal}

The International Journal of Nanomedicine is an international, peerreviewed journal focusing on the application of nanotechnology in diagnostics, therapeutics, and drug delivery systems throughout the biomedical field. This journal is indexed on PubMed Central, MedLine, CAS, SciSearch ${ }^{\mathbb{R}}$, Current Contents ${ }^{\mathbb{B}} /$ Clinical Medicine, $^{2}$

Journal Citation Reports/Science Edition, EMBase, Scopus and the Elsevier Bibliographic databases. The manuscript management system is completely online and includes a very quick and fair peer-review system, which is all easy to use. Visit http://www.dovepress.com/ testimonials.php to read real quotes from published authors. 